\title{
Covid-19: Sweden should have done more, says architect of country's strategy
}

\author{
Jacqui Wise
}

London

The epidemiologist responsible for Sweden's controversial lighter lockdown policy has conceded that the country could have done more to curb the spread of covid-19.

Sweden has a far higher death rate from covid-19 than its neighbouring Scandinavian countries, which imposed stricter measures.

In an interview with Swedish Radio, Anders Tegnell agreed with the interviewer that too many people had died in the country. "There is quite obviously a potential for improvement in what we have done in Sweden," he said.

By 3 June there had been 4542 covid-19 related deaths in Sweden, whereas the number was only 580 in Denmark, 321 in Finland, and 237 in Norway, the latest figures from the John Hopkins University show. ${ }^{2}$ Deaths per 100000 population are 43.88 in Sweden, 10.00 in Denmark, 5.80 in Finland, and 4.46 in Norway, although Sweden's per capita tally still remains lower than that in Belgium (83.22), the UK (59.34), Spain (58.06), and Italy 55.48.

However, Sweden has had the highest per capita death rate in the world for some days in the past month. The number of covid-19 deaths in Sweden was 5.29 deaths per million people a day in a rolling seven day average to 2 June, ${ }^{3}$ which compared with 4.48 in the UK. However, on 3 June the UK once again had the highest death rate (4.88, versus 4.85 in Sweden).

Up until now Tegnell, who is Sweden's state epidemiologist, has been defensive of the country's more relaxed policy. There was no lockdown, and instead Sweden relied on voluntary social distancing, a ban on gatherings of more than 50 people, and stopping visits to care homes for elderly people. People were asked-but not ordered - to avoid non-essential travel and not to go out if they were elderly or ill. Shops, restaurants, bars, and gyms have remained open, as have schools for under 16s.
Tegnell told the radio programme: "If we would encounter the same disease, with exactly what we know about it today, I think we would land midway between what Sweden did and what the rest of the world did." It would be "good to know exactly what to shut down to curb the spread of infection better," he added.

However, at a press conference later the same day Tegnell said he thought Sweden still basically had the right strategy.

Last week Norway and Denmark opened their borders to each other but not to Sweden. Sweden's government said on 1 June that it would appoint a commission to investigate the country's approach to coronavirus, bowing to pressure from opposition politicians.

Claudia Hanson, an epidemiologist at Sweden's Karolinska Institute, told The BMJ, "I am very happy that [Tegnell] is admitting that more could have been done." She added, "What is now needed is to put all efforts into breaking the transmission of disease and establish a testing, contact tracing, and isolation system."

She said that Tegnell must strongly advise people they must stay at home if they have been in contact with someone with covid-19 symptoms, to further diminish the spread of the disease.

1 Sverige Radio. Tegnell: Fler åtgärder hade behövts. 3 Jun 2020. https://sverigesradio.se/ sida/artikel.aspx?programid $=83 \&$ artikel $=7487188$

2 John Hopkins University. Covid-19 dashboard. https://coronavirus.jhu.edu/map.html. 3 Daily confirmed covid-19 deaths per million, rolling 7-day average. Our World in Data. https://ourworldindata.org/grapher/daily-covid-deaths-per-million-7-day-average.

This article is made freely available for use in accordance with BMJ's website terms and conditions for the duration of the covid-19 pandemic or until otherwise determined by BMJ. You may use, download and print the article for any lawful, non-commercial purpose (including text and data mining) provided that all copyright notices and trade marks are retained.

https://bmj.com/coronavirus/usage 